\title{
Latent Root Regression untuk Mengatasi Multikolinearitas
}

\author{
Desy Pramesti Untari ${ }^{1}{ }^{*}$, Mathilda Susanti ${ }^{1}$ \\ ${ }^{1}$ Jurusan Pendidikan Matematika, Fakultas Matematika dan Ilmu Pengetahuan Alam, Universitas \\ Negeri Yogyakarta, Jalan Colombo No. 1, Karangmalang, Yogyakarta 55281, Indonesia. \\ * Corresponding Author. E-mail: desy.xenia@ gmail.com, Telp: +62274565411
}

Received: 10 November 2016; Revised:7 June 2017; Accepted: 10 June 2017

\begin{abstract}
Abstrak
Salah satu metode yang dapat digunakan untuk mengatasi masalah multikolinearitas pada model regresi adalah latent root regression. Latent root regression merupakan perluasan dari principal component regression. Tujuan penelitian ini adalah untuk melakukan analisis latent root regression dalam mengatasi multikolinearitas yang diterapkan pada faktor-faktor yang mempengaruhi IHSG di Bursa Efek Indonesia. Variabel-variabel yang digunakan pada penelitian ini adalah IHSG, jumlah uang beredar, kurs rupiah terhadap dolar AS, harga emas dunia dan Indeks Dow Jones. Hasil penelitian yang diperoleh adalah faktor jumlah uang beredar, kurs rupiah terhadap dolar AS, harga emas dunia dan Indeks Dow Jones berpengaruh terhadap IHSG, namun terjadi multikolinearitas diantara faktor-faktor tersebut sehingga diselesaikan dengan latent root regression. Kemudian analisis latent root regression tersebut dibandingkan dengan analisis principal component regression pada faktor-faktor yang mempengaruhi IHSG di Bursa Efek Indonesia yang hasilnya adalah latent root regression lebih baik daripada principal component regression karena $R_{a d j}^{2}$ lebih tinggi dan asumsi regresi lebih banyak dipenuhi pada latent root regression.
\end{abstract}

Kata Kunci: latent root regression, multikolinearitas, IHSG.

\section{Latent Root Regression to Solve Multicolinearity}

\begin{abstract}
One of methods can be used to overcome the problem of multicollinearuty in a regression model is latent root regression. Latent root regression is an extension of principal component regression. The purpose of this research is to perfom a latent root regression analysis in solving multicollinearity on the factors that affect JSX Composite in Indonesia Stock Exchange. The variables used in this research are JSX Composite, money supply, rupiah exchange rate against the US dollar, gold price and DJI. The research result obtained are the factors of money supply, rupiah exchange rate against the US dollar, gold price and DJI affect JSX Composite, but multicollinearity occur among these factors thus solved by latent root regression. Then the latent root regression analysis is compared with principal component regression on the factors that affect JSX Composite in Indonesia Stock Exchange that the result is better than latent root regression of principal component regression because $R_{a d j}^{2}$ is higher and regression assumptions more fulfilled in latent root regression.
\end{abstract}

Keywords: latent root regression, multicollinearity, JSX composite

How to Cite: Untari, D., \& Susanti, M. (2017). Latent root regression dalam mengatasi multikolinearitas. PYTHAGORAS: Jurnal Pendidikan $\quad$ Matematika, $\quad 12(1), \quad 23-32$. doi:http://dx.doi.org/10.21831/pg.v12i1.11633

Permalink/DOI: http://dx.doi.org/10.21831/pg.v12i1.11633 
Pythagoras, 12 (1), 2017 - 24

Desy Pramesti Untari, Mathilda Susanti

\section{PENDAHULUAN}

Statistika seringkali digunakan untuk memecahkan masalah dalam berbagai bidang kehidupan sehari-hari, baik di bidang ekonomi, psikologi, sosial maupun di bidang lainnya. Salah satu teknik statistika yang banyak digunakan adalah analisis regresi.

Analisis regresi adalah analisis mengenai seberapa besar pengaruh variabel bebas terhadap variabel tidak bebas (Sunyoto, 2012, p.181). Analisis regresi terbagi menjadi dua macam, yaitu analisis regresi linear dan analisis regresi non-linear, linear yang dimaksud adalah linear dalam parameter. Berdasarkan banyak variabel bebas, analisis regresi linear terbagi atas analisis regresi linear sederhana yang hanya terdiri dari satu variabel bebas dan analisis regresi linear berganda yang terdiri dari dua atau lebih variabel bebas. Analisis regresi linear yang sering digunakan adalah analisis regresi linear berganda. Pada analisis regresi linear berganda, terdapat asumsi-asumsi yang harus dipenuhi, yaitu normalitas, tidak terjadi heterokedastisitas, tidak terjadi autokorelasi dan tidak terjadi multikolinearitas.

Salah satu metode penaksiran parameter yang banyak digunakan untuk menduga koefisien regresi adalah metode kuadrat terkecil. Pendugaan koefisien regresi menggunakan metode kuadrat terkecil, khususnya metode kuadrat terkecil terkadang tidak bisa dilakukan karena tidak terpenuhinya asumsi-asumsi analisis regresi linear berganda. Salah satu asumsi yang tidak terpenuhi tersebut adalah terjadi multikolinearitas.

Multikolinearitas artinya terdapat hubungan linear atau korelasi yang tinggi antar variabel bebas dalam model regresi. Terjadinya multikolinearitas akan menimbulkan masalah dalam model regresi. Dampak yang dapat ditimbulkan, yaitu variansi penduga kuadrat terkecil besar dan tidak efisien sehingga menghasilkan galat baku dan interval kepercayaan parameter model regresi yang lebih besar, uji $t$ menghasilkan variabel bebas tidak berpengaruh signifikan terhadap variabel tidak bebas, dan penduga kuadrat terkecil dan galat baku menjadi sensitif terhadap perubahan kecil dalam data (Gujarati, 2006, p.66).

Salah satu teknik yang dapat digunakan untuk mengatasi multikolinearitas adalah latent root regression. Latent root regression merupakan perluasan dari principal component regression. Perbedaannya terletak pada pembentukan komponen utama dan kriteria pemilihan komponen utama. Pembentukan komponen utama pada principal component regression hanya melibatkan variabel-variabel bebasnya saja, hal ini memungkinkan komponen utama yang berguna untuk prediksi akan memberi resiko (Vigneau \& Qannari, 2002, p.232). Sedangkan pembentukan komponen utama pada latent root regression melibatkan variabel-variabel bebas maupun variabel tidak bebas, sehingga komponen utama pada latent root regression mengandung lebih banyak informasi dibandingkan komponen utama pada principal component regression (Vigneau \& Qannari, 2002, p.233).

Terdapat beberapa penelitian tentang principal component regression dan latent root regression, salah satunya oleh Marcus, dkk (2012) yang mencoba mengatasi multikolinearitas pada studi kasus curah hujan di Kota Ambon menggunakan regresi komponen utama sehingga diperoleh persamaan regresi komponen utamanya, selain itu hasil simulasi oleh Riyantini, dkk (2014) yaitu latent root regression dapat mengatasi multikolinearitas dengan tuntas dan menghasilkan persamaan regresi yang akurat.

Pada penelitian ini, analisis latent root regression diterapkan pada faktor-faktor yang mempengaruhi IHSG di Bursa Efek Indonesia (BEI). IHSG (Indeks Harga Saham Gabungan) adalah perubahan atau pergerakan harga saham seluruh emiten di BEI yang diukur pada setiap akhir bulan (Kewal, 2012, p.60) yang menjadi salah satu indikator bagi investor ketika akan membeli atau menjual saham. Banyak teori dan penelitian mengungkapkan bahwa perubahan IHSG dipengaruhi oleh banyak faktor, di antaranya jumlah uang beredar, kurs rupiah terhadap dolar AS, harga emas dunia dan Indeks Dow Jones. Hasil penelitian oleh Witjaksono (2010) menyatakan bahwa kurs rupiah terhadap dolar AS berpengaruh negatif terhadap IHSG, sedangkan harga emas dunia dan Indeks Dow Jones berpengaruh positif terhadap IHSG. Selain itu, hasil penelitian oleh Ernawati (2014) menyatakan bahwa kurs rupiah terhadap dolar AS berpengaruh negatif terhadap IHSG, sedangkan jumlah uang beredar berpengaruh positif terhadap IHSG. Kemampuan investor dalam memahami faktor-faktor yang mempengaruhi IHSG akan sangat berguna dalam pengambilan keputusan investasi (Samsul, 2006, p.201).

Menurut teori, terdapat hubungan di antara keempat faktor tersebut. Pada umumnya 
Pythagoras, 12 (1), 2017 - 25

Desy Pramesti Untari, Mathilda Susanti

harga emas dunia berkorelasi negatif dengan kurs rupiah terhadap dolar AS. Hal ini disebabkan oleh kecenderungan untuk investasi dalam bentuk dolar AS ketika kurs rupiah terhadap dolar AS tinggi, dan kecenderungan untuk investasi emas ketika kurs rupiah terhadap dolar AS turun. Jika kurs rupiah terhadap dolar AS naik, maka investor akan lebih menyukai investasi dalam bentuk dolar AS. Begitu pula dengan kenaikan harga emas akan mendorong investor untuk memilih berinvestasi dengan emas, sebab dengan resiko yang lebih rendah, emas dapat memberikan hasil timbal balik yang baik dengan kenaikan harganya (Prayitno, 2012, p.422). Sedangkan indeks Dow Jones dan jumlah uang beredar berkorelasi positif dengan kurs rupiah terhadap dolar AS. Meningkatnya kurs rupiah terhadap dolar AS akan meningkatkan biaya impor barang (Nopirin, 2000, p.266). Peningkatan biaya impor ini berdampak pada peningkatan kinerja pasar saham luar negeri yang pada akhirnya akan menaikkan indeks saham luar negeri termasuk Indeks Dow Jones. Peningkatan biaya impor berarti juga meningkatnya harga barang. Menurut hukum permintaan dan penawaran, harga barang dan jumlah uang beredar berbanding lurus. Jika harga barang naik maka jumlah uang beredar naik (Hasibuan, 2009, p.13).

Berdasarkan uraian mengenai hubungan diantara keempat faktor tersebut, maka diduga terdapat korelasi yang tinggi antar faktor tersebut yang dapat menimbulkan multikolinearitas pada analisis regresi linear berganda sehingga harus diatasi, yaitu dengan latent root regression. Kemudian hasil analisis tersebut akan dibandingkan dengan hasil analisis principal component regression untuk mengetahui metode mana yang lebih baik dalam mengatasi multikolinearitas pada faktor-faktor yang mempengaruhi IHSG di Bursa Efek Indonesia dilihat dari hasil uji koefisien determinasi, uji parameter dan uji asumsi model regresi.

\section{METODE}

\section{Principal Component Regression}

Principal component regression atau regresi komponen utama merupakan salah satu metode yang dapat digunakan untuk mengatasi multikolinearitas. Principal component regression atau regresi komponen utama merupakan teknik meregresikan komponen utama dengan variabel tidak bebas (Marcus dkk, 2012, p.32). Principal component regression akan menghasilkan variabel-variabel baru yang merupakan kombinasi linear dari variabelvariabel bebas asal dan antar variabel baru yang sifatnya saling bebas. Variabel-variabel yang baru tersebut dinamakan komponen utama, yang selanjutnya diregresikan dengan variabel tidak bebasnya.

Secara umum tahapan menentukan komponen utama untuk data dengan skala pengukuran tidak sama yaitu: (1) membuat matriks $\boldsymbol{Z}$, (2) menghitung matriks $\boldsymbol{Z}^{\prime} \boldsymbol{Z}$, (3) menghitung akar laten (nilai eigen) $\lambda_{1}, \lambda_{2}, \ldots, \lambda_{k}$, (4) menghitung vektor eigen $\gamma_{j}$, (5) membentuk komponen utama $K_{j}$ yang saling ortogonal sesamanya, (6) membentuk model regresi komponen utama, dan (7) membentuk model persamaan regresi ke dalam bentuk variabel asal. Masing-masing tahapan dilakukan dengan menggunakan aturan dan rumus sebagaimana yang ditunjukkan pada Tabel 1.

\section{Latent Root Regression}

Latent root regression atau regresi akar laten merupakan salah satu cara yang dapat digunakan untuk mengatasi multikolinearitas pada analisis regresi linear berganda. Langkahlangkah analisis latent root regression dapat disajikan dalam Gambar 1.

Langkah pertama dalam analisis latent root regression adalah melakukan pembakuan data pada variabel tidak bebas $(Y)$ dan variabel bebas $(X)$ untuk mendapatkan matriks korelasi $\left(\boldsymbol{Z}^{*}\right)$, yang dapat dituliskan dengan rumus:

$$
\begin{aligned}
& \boldsymbol{Z}^{*}=\left[\boldsymbol{Y}^{*} \mid \boldsymbol{X}^{*}\right] \\
& \quad \text { (Draper \& Smith, 1992, p.317): }
\end{aligned}
$$

\section{Dengan}

$\boldsymbol{Y}^{*}$ : matriks $\boldsymbol{Y}$ yang telah dibakukan,

$\boldsymbol{X}^{*}$ : matriks $\boldsymbol{X}$ yang telah dibakukan

$\boldsymbol{Z}^{*}$ : penggabungan matriks $\boldsymbol{Y}$ dan $\boldsymbol{X}$ yang telah dibakukan.

Pembakuan data pada variabel tidak bebas dan variabel bebas diperoleh melalui rumus:

$$
\begin{aligned}
& Y_{i}^{*}=\frac{Y_{i}-\bar{Y}}{\sqrt{\sum_{i=1}^{n}\left(Y_{i}-\bar{Y}\right)^{2}}}, i=1,2, \ldots, n \\
& \text { dan } \\
& X_{i j}^{*}=\frac{X_{i j}-\bar{X}_{j}}{\sqrt{\sum_{i=1}^{n}\left(X_{i j}-\bar{X}_{j}\right)^{2}}}, i=1,2, \ldots, n ; j=1,2,3, \ldots, k(1.10)
\end{aligned}
$$

(Draper \& Smith, 1992, p.317) 
Pythagoras, 12 (1), 2017 - 26

Desy Pramesti Untari, Mathilda Susanti

Tabel 1. Tahapan Menentukan Komponen Utama untuk Data dengan Skala Pengukuran tidak Sama

\begin{tabular}{|c|c|}
\hline Langkah-langkah & Keterangan \\
\hline 1 Membuat matriks $\boldsymbol{Z}$ & 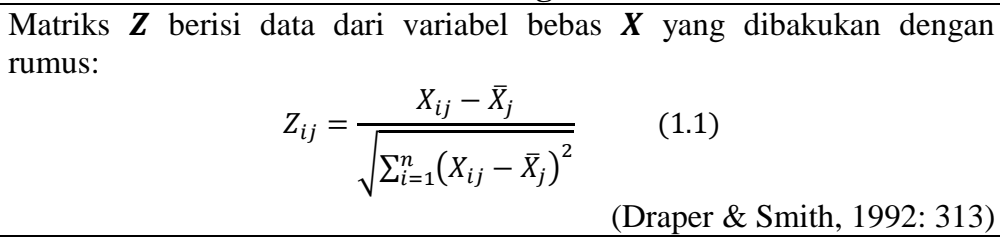 \\
\hline$2 \longdiv { \text { Menghitung } \boldsymbol { Z } ^ { \prime } \boldsymbol { Z } }$ & $\boldsymbol{Z}^{\prime} \boldsymbol{Z}$ merupakan matriks korelasi dari matriks $\boldsymbol{Z}$ \\
\hline $\begin{array}{l}3 \text { Menghitung akar laten (nilai } \\
\text { eigen) } \lambda_{1}, \lambda_{2}, \ldots, \lambda_{k}\end{array}$ & $\begin{array}{l}\text { Diperoleh dari persamaan: } \\
\qquad\left|\boldsymbol{Z}^{\prime} \boldsymbol{Z}-\lambda \boldsymbol{I}\right|=0\end{array}$ \\
\hline 4 Menghitung vektor eigen $\gamma_{j}$ & $\begin{array}{l}\text { Diperoleh dari masing-masing nilai eigen } \lambda_{j} \text { yang memenuhi suatu sistem } \\
\text { persamaan homogen: } \\
\qquad\left(\boldsymbol{Z}^{\prime} \boldsymbol{Z}-\lambda_{j} \boldsymbol{I}\right) \gamma_{j}=0 \\
\text { dimana } \gamma_{j}=\left(\gamma_{1 j}, \gamma_{2 j}, \gamma_{3 j}, \ldots, \gamma_{k j}\right)\end{array}$ \\
\hline $\begin{array}{l}5 \text { Membentuk komponen utama } K_{j} \\
\text { yang saling ortogonal sesamanya }\end{array}$ & $\begin{array}{l}\text { Komponen utama } K_{j} \text { yang saling ortogonal sesamanya melalui suatu } \\
\text { hubungan: } \\
\qquad K_{j}=\gamma_{1 j} Z_{1}+\gamma_{2 j} Z_{2}+\cdots+\gamma_{k j} Z_{k} \\
\text { Komponen utama yang dipilih adalah yang bersesuaian dengan akar laten } \\
\text { lebih besar dari } 1 \text { (Draper \& Smith, 1992, p.313). }\end{array}$ \\
\hline $\begin{array}{l}6 \text { Membentuk model regresi } \\
\text { komponen utama. }\end{array}$ & 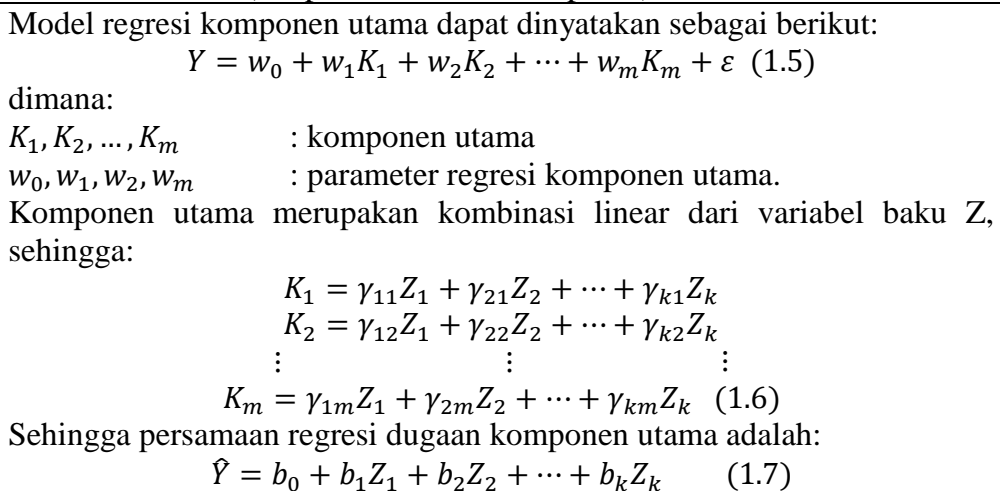 \\
\hline $\begin{array}{l}7 \text { Membentuk model persamaan } \\
\text { regresi ke dalam bentuk variabel } \\
\text { asal }\end{array}$ & Diperoleh dengan cara mensubstitusikan Persamaan (1.7) dan (1.1). \\
\hline
\end{tabular}

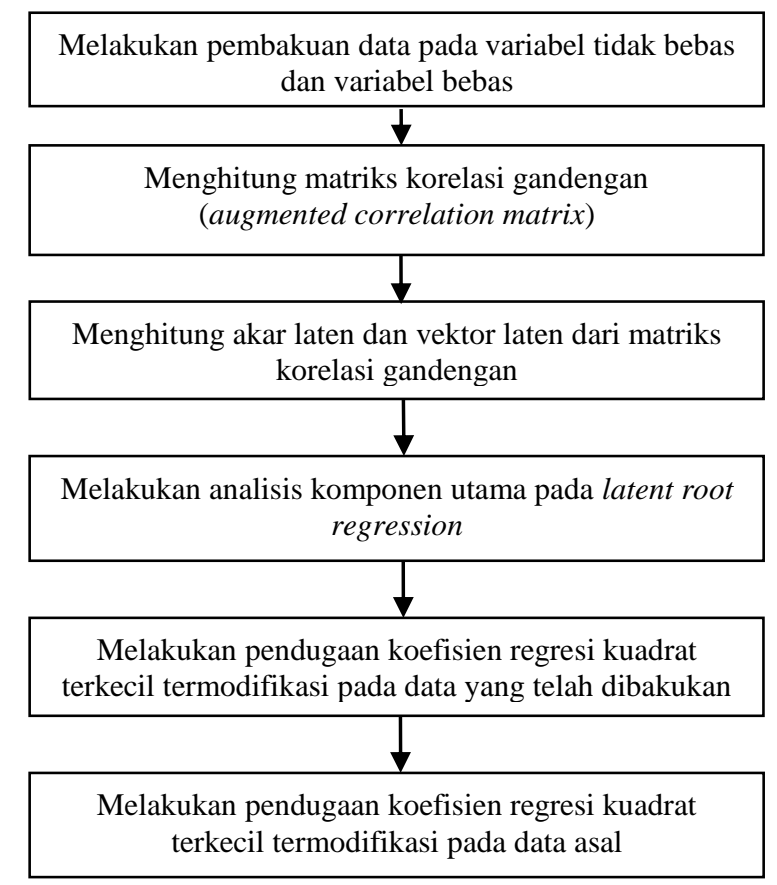

Gambar 1. Langkah-Langkah Latent Root Regression 
Langkah selanjutnya adalah menghitung matriks korelasi gandengan (augmented correlation matrix), yaitu $\boldsymbol{Z}^{* \prime} \boldsymbol{Z}^{*}$. Akar laten $\left(\lambda_{j}\right)$ dan vektor laten $\left(\boldsymbol{\gamma}_{\boldsymbol{j}}\right)$ pada analisis latent root regression diperoleh dari matriks korelasi gandengan ini yang memenuhi persamaan berikut:

dan

$$
\left|Z^{* \prime} Z^{*}-\lambda_{j} I\right|=0
$$

$$
\left(\boldsymbol{Z}^{* \prime} \boldsymbol{Z}^{*}-\lambda_{j} \boldsymbol{I}\right) \boldsymbol{\gamma}_{\boldsymbol{j}}=\mathbf{0}
$$

Setelah diperoleh akar laten dan vektor laten dari matriks korelasi gandengannya, selanjutnya melakukan analisis komponen utama. Komponen utama pada latent root regression diperoleh dengan menggunakan rumus:

dimana

$$
C_{j}=\gamma_{0 j} Y^{*}+\gamma_{j}^{0} X^{*}
$$

$\gamma_{j}^{\prime}=\left(\gamma_{0 j}, \gamma_{1 j}, \gamma_{2 j}, \ldots, \gamma_{k j}\right)$, dan

$\boldsymbol{\gamma}_{\boldsymbol{j}}^{\mathbf{0}}=\left(\gamma_{1 j}, \gamma_{2 j}, \ldots, \gamma_{k j}\right)$.

(Vigneau \& Qannari, 2002, p.233)

Pada latent root regression, elemen pertama (koefisien $Y$ ) yaitu $\gamma_{0 j}$ setiap vektor laten digunakan untuk meramalkan variabel tidak bebas oleh vektor laten tersebut. Untuk suatu $j$, bila nilai akar laten dan vektor laten yang bersesuaian dengan akar laten kecil atau mendekati nilai nol, hal tersebut menandakan adanya hampir kesingularan dalam data serta buruknya keteramalan variabel tidak bebas tersebut (Draper \& Smith, 1992, p.317). Semakin besar elemen pertama vektor laten tersebut, maka semakin bermanfaat vektor itu dalam meramalkan variabel tidak bebasnya dan sebaliknya. Adanya nilai akar laten yang kecil memungkinkan adanya ketergantungan atau ketidakbebasan linear di antara variabel-variabel bebas. Semakin kecil nilai akar laten, semakin kuat ketidakbebasan linear tersebut. Akar laten yang bernilai nol menandakan adanya singularitas, dan elemen pertama dari suatu vektor laten yang bernilai nol menandakan bahwa vektor laten tersebut tidak mempunyai kontribusi variansi dalam variabel tidak bebas (Sharma \& James, 1981, p.157).

Oleh sebab itu tidak ada kriteria yang pasti dalam menentukan akar laten dan vektor laten yang digunakan untuk membentuk komponen utama. Untuk menentukan komponen utama yang akan digunakan, pedoman yang disarankan Webster, et. al (1974, p.518) yaitu dengan membuang komponen utama yang bersesuaian dengan nilai akar laten $\lambda_{j} \leq 0,05$ dan elemen pertama vektor laten $\left|\gamma_{0 j}\right|<0,10$, sedangkan Sharma, et. al (1981, p.157) membuang akar laten $\left|\lambda_{j}\right|<0,10$ dan elemen pertama vektor laten $\left|\gamma_{0 j}\right|<0,30$ serta Midi, et. al (2009: 5) membuang akar laten $\lambda_{j}<0,20$ dan elemen pertama vektor laten $\left|\gamma_{0 j}\right|<0,10$ dalam penelitian mereka. Komponen utama yang terpilih nantinya dapat digunakan untuk mendeteksi apakah masalah multikolinearitas sudah teratasi dengan cara meregresikan komponen utama yang terpilih dengan variabel tidak bebas (Riyantini dkk, 201, p.15).

Persamaan kuadrat terkecil untuk suatu model tertentu adalah kombinasi linear terbaik dari semua vektor laten. Dengan membuang vektor laten yang akar laten dan elemen pertama vektor laten yang bersesuaian kecil, maka akan diperoleh persamaan kuadrat terkecil yang telah termodifikasi. Prosedur termodifikasi ini menghasilkan penduga yang bias (Draper \& Smith, 1992, p.318). Setelah menentukan vektor mana yang tetap dipertahankan, selanjutnya menghitung vektor koefisien kuadrat terkecil termodifikasi dengan rumus (Webster, et al, 1974, p.515):

$\widehat{\boldsymbol{\beta}}^{*}=\left[\begin{array}{c}\hat{\beta}_{1}^{*} \\ \hat{\beta}_{2}^{*} \\ \vdots \\ \hat{\beta}_{k}^{*}\end{array}\right]=c \sum_{j}^{*} \gamma_{0 j} \lambda_{j}^{-1}\left[\begin{array}{c}\gamma_{1 j} \\ \gamma_{2 j} \\ \vdots \\ \gamma_{k j}\end{array}\right], j=0,1,2, \ldots, k$

dengan $c$ adalah konstanta yang diperoleh dengan rumus:

dan

$$
c=-\left\{\sum_{j}^{*} \gamma_{0 j}^{2} \lambda_{j}^{-1}\right\}^{-1}\left\{\sum_{i=1}^{n}\left(Y_{i}-\bar{Y}\right)^{2}\right\}^{\frac{1}{2}}
$$

$\hat{\beta}_{0}^{*}=\bar{Y}$

dengan:

$\sum_{j}^{*}$ : penjumlahan dari nilai-nilai $j$ yang vektornya tetap dipertahankan dalam langkah sebelumnya.

$\hat{\beta}_{0}^{*}, \hat{\beta}_{1}^{*}, \hat{\beta}_{2}^{*}, \ldots, \hat{\beta}_{k}^{*}$ : koefisien regresi bagi variabel yang telah dibakukan.

Langkah terakhir dalam analisis latent root regression adalah membentuk model regresi kuadrat terkecil termodifikasi bagi variabel asal, dengan rumus sebagai berikut:

$\hat{\beta}_{j}=\frac{\widehat{\beta}_{j}^{*}}{\sqrt{\sum_{i}^{n}\left(X_{i j}-\bar{X}_{j}\right)^{2}}}, j=1,2, \ldots, k$

Sedangkan perhitungan koefisien regresi untuk $\hat{\beta}_{0}$ diperoleh dengan rumus:

$\hat{\beta}_{0}=\bar{Y}-\hat{\beta}_{1} \bar{X}_{1}-\hat{\beta}_{2} \bar{X}_{2}-\cdots-\hat{\beta}_{k} \bar{X}_{k}$ 
Pythagoras, 12 (1), 2017 - 28

Desy Pramesti Untari, Mathilda Susanti

\section{HASIL DAN PEMBAHASAN}

\section{Analisis Regresi Linear Berganda}

Data yang digunakan dalam penelitian ini berupa data sekunder dan merupakan data time series bulanan periode Januari 2012-Desember 2015. Variabel tidak bebas yang digunakan yaitu IHSG $(Y)$ yang diperoleh dari www.bps.go.id dan variabel bebas yang digunakan yaitu jumlah uang beredar $\left(X_{1}\right)$ yang diperoleh dari www.bps.go.id, kurs rupiah terhadap dolar AS $\left(X_{2}\right)$ yang diperoleh dari www.bi.go.id, harga emas dunia $\left(X_{3}\right)$ yang diperoleh dari www.id.investimg.com dan Indeks Dow Jones $\left(X_{4}\right)$ yang diperoleh dari www.id.investing.com.

Mula-mula dilakukan analisis regresi linear berganda terlebih dahulu untuk mengetahui hubungan variabel bebas dengan variabel tidak bebas, diperoleh persamaan dugaan regresi sebagai berikut:

$$
\begin{array}{cc}
\hat{Y}=-1086,777 \\
0,370 X_{4}
\end{array}+0,001 X_{1}-0,480 X_{2}+0,926 X_{3}+
$$

Setelah diperoleh persamaan regresinya, selanjutnya dilakukan uji koefisien determinasi, uji $F$, uji $t$ dan uji asumsi. Diperoleh koefisien determinasi $R_{a d j}^{2}=0,827$ yang artinya sebesar $82,7 \%$ keragaman variabel tidak bebas dapat diterangkan oleh variabel-variabel bebas yang digunakan.

Pada uji $F$ diperoleh bahwa $p$-value $=0$ yang berarti bahwa secara simultan variabelvariabel bebas yang digunakan berpengaruh signifikan terhadap variabel tidak bebas. Pada uji $t$ diperoleh bahwa semua nilai $p-$ value -0 untuk $X_{1}, X_{2}$ dan $X_{4}$, dan $p$-value $=0,014$ untuk $X_{3}$ yang artinya variabel-variabel bebas secara parsial berpengaruh signifikan terhadap variabel tidak bebas.

Kemudian dilakukan uji asumsi regresi yang terdiri dari normalitas, heterokedastisitas, autokorelasi dan multikolinearitas. Uji normalitas dilakukan melalui Uji Kolmogorov-Smirnov yang diperoleh $p$-value $=0,943$, yang artinya bahwa galat berdistribusi normal. Uji heterokedastisitas dilakukan melalui Uji Glejser yang diperoleh $p$-value $=0,873$ untuk $X_{1}, p-$ value $=0,92$ untuk $X_{2}, p$-value $=0,246$ untuk $X_{3}$, dan $p$-value $=0,407$ untuk $X_{4}$, yang artinya tidak terjadi heterokedastisitas. Uji autokorelasi dilakukan melalui Uji Run yang diperoleh $p-$ value $=0,307$, yang artinya tidak terjadi autokorelasi. Uji multikolinearitas dilakukan melalui uji korelasi parsial $(r)$ dan uji VIF. Multikolinearitas ditandai dengan $|r|>0,75$ atau
$V I F>10$. Tabel 2berikut ini hasil uji korelasi parsial dan VIF:

Tabel 2. Uji Multikolinearitas

\begin{tabular}{cccccc}
\hline $\boldsymbol{r}$ & $\boldsymbol{X}_{\mathbf{1}}$ & $\boldsymbol{X}_{\mathbf{2}}$ & $\boldsymbol{X}_{\mathbf{3}}$ & $\boldsymbol{X}_{\mathbf{4}}$ & $\boldsymbol{V I F}$ \\
\hline$X_{1}$ & 1 & $-0,825$ & $-0,011$ & $-0,470$ & 26,952 \\
$X_{2}$ & $-0,825$ & 1 & 0,256 & 0,199 & 20,215 \\
$X_{3}$ & $-0,011$ & 0,256 & 1 & 0,538 & 8,675 \\
$X_{4}$ & $-0,470$ & 0,199 & 0,538 & 1 & 10,516 \\
\hline
\end{tabular}

Dari Tabel 2 dapat dilihat bahwa terdapat nilai $|r|>0,75$ yaitu korelasi antara $X_{1}$ dan $X_{2}$ sebesar 0,825 dan terdapat $V I F>10$ yaitu di antara $X_{1}, X_{2}$ dan $X_{4}$ sehingga dapat disimpulkan bahwa terjadi multikolinearitas pada model regresi.

\section{Analisis Principal Component Regression}

Sebelum dilakukan analisis latent root regression dilakukan analisis principal component regression pada faktor-faktor yang mempengaruhi IHSG di Bursa Efek Indonesia dilakukan untuk membandingkan apakah latent root regression lebih baik daripada principal component regression dalam mengatasi multikolinearitas.

Langkah pertama adalah melakukan pembakuan data pada variabel bebas berdasarkan Persamaan (1.1). Diperoleh matriks $\boldsymbol{Z}$ sebagai berikut:

$$
\boldsymbol{Z}=\left[\begin{array}{cccc}
-0,236 & -0,196 & 0,247 & -0,235 \\
-0,238 & -0,203 & 0,228 & -0,209 \\
-0,201 & -0,191 & 0,201 & -0,189 \\
-0,216 & -0,190 & 0,197 & -0,189 \\
\vdots & \vdots & \vdots & \vdots \\
0.246 & 0,233 & -0,206 & 0,143
\end{array}\right]
$$

Langkah selanjutnya adalah menghitung nilai eigen dan vektor eigen dari matriks korelasi yaitu $\boldsymbol{Z}^{\prime} \boldsymbol{Z}$ berdasarkan Persamaan (1.2) dan (1.3). Diperoleh nilai eigen dan vektor eigen matriks korelasinya dapat dilihat Tabel 3.

Tabel 3. Nilai Eigen dan Vektor Eigen dari $\boldsymbol{Z}^{\prime} \boldsymbol{Z}$

\begin{tabular}{cccccc}
\hline \multirow{2}{*}{ No. } & \multirow{2}{*}{$\boldsymbol{\lambda}_{\boldsymbol{j}}$} & $\boldsymbol{Z}_{\mathbf{1}}$ & $\boldsymbol{Z}_{\mathbf{2}}$ & $\boldsymbol{Z}_{\mathbf{3}}$ & $\boldsymbol{Z}_{\mathbf{4}}$ \\
\cline { 3 - 6 } & & $\boldsymbol{\gamma}_{\mathbf{1} \mathbf{j}}$ & $\boldsymbol{\gamma}_{\mathbf{2} \mathbf{j}}$ & $\boldsymbol{\gamma}_{\mathbf{3} \mathbf{j}}$ & $\boldsymbol{\gamma}_{\mathbf{4} \mathbf{j}}$ \\
\hline 1. & $\lambda_{1}=3,7728$ & 0,506 & 0,501 & $-0,496$ & 0,498 \\
2. & $\lambda_{2}=0.1282$ & 0,401 & 0,584 & 0,533 & $-0,463$ \\
3. & $\lambda_{3}=0.0769$ & 0,158 & $-0,177$ & 0,679 & 0,695 \\
4. & $\lambda_{4}=0.0221$ & $-0,748$ & 0,614 & 0,093 & 0,235 \\
\hline
\end{tabular}

Kriteria pemilihan komponen utama yang digunakan yaitu dengan memilih komponen utama yang bersesuaian dengan nilai eigen lebih besar dari satu (Draper \& Smith, 1992, p.313). Dari Tabel 2 dapat dilihat bahwa nilai eigen yang lebih besar dari satu hanya satu yaitu 
$\lambda_{1}=3,7728$, sehingga komponen utama yang terbentuk berdasarkan Persamaan (1.4) adalah

$K_{1}=0,506 Z_{1}+0,501 Z_{2}-0,496 Z_{3}+0,498 Z_{4}(2.3)$

dimana $K_{1}$ adalah komponen utama yang terbentuk dari vektor eigen yang bersesuaian dengan $\lambda_{1}=3,7728$.

Nilai-nilai dari $K_{1}$ diperoleh dengan mensubstitusi Persamaan (2.2) dan (2.3), sehingga diperoleh matriks $\boldsymbol{K}_{\mathbf{1}}$ sebagai berikut:

$\boldsymbol{K}_{\mathbf{1}}=\left[\begin{array}{c}-3,130 \\ -3,012 \\ -2,745 \\ -2,713 \\ \vdots \\ 2,841\end{array}\right]$

Kemudian komponen utama tersebut diregresikan dengan variabel tidak bebas untuk dilakukan uji koefisien determinasi, uji parameter dan uji asumsi. Diperoleh persamaan regresi sebagai berikut:

$\widehat{Y}=4634,625+139,995 K_{1}$

Diperoleh pula koefisien determinasi $R_{a d j}^{2}=0,366$ yang artinya sebesar $36,6 \%$ keragaman variabel tidak bebas dapat diterangkan oleh variabel-variabel bebas yang digunakan.

Pada uji $t$ diperoleh bahwa nilai $p-$ value $=0$ untuk $K_{1}$, yang artinya variabel bebas berpengaruh signifikan terhadap variabel tidak bebas. Selanjutnya dilakukan uji asumsi regresi yang terdiri dari normalitas, heterokedastisitas, dan autokorelasi. Uji normalitas dilakukan melalui Uji Kolmogorov-Smirnov yang diperoleh $p$-value $=0,98$, yang artinya bahwa galat berdistribusi normal. Uji heterokedastisitas dilakukan melalui Uji Glejser yang diperoleh $p$-value $=0,000=0$ untuk $K_{1}$ yang artinya terjadi heterokedastisitas. Uji autokorelasi dilakukan melalui Uji Run yang diperoleh $p-$ value $=0$, yang artinya terjadi autokorelasi.

Langkah terakhir adalah membentuk model regresi ke dalam variabel asal dengan mensubstitusi Persamaan (2.5) dan (2.3), sehingga diperoleh persamaan regresi dugaan berikut:

$$
\begin{aligned}
\hat{Y}= & 4467,227+0,00002 X_{1}+0,00634 X_{2}- \\
& 0,0464 X_{3}+0,00549 X_{4}
\end{aligned}
$$

\section{Analisis Latent Root Regression}

Selanjutnya analisis latent root regression akan diterapkan pada faktor-faktor yang mempengaruhi IHSG di Bursa Efek Indonesia. Langkah pertama adalah melakukan pembakuan data pada variabel tidak bebas dan variabel bebas berdasarkan Persamaan (1.9) dan (1.10). Diperoleh matriks $\boldsymbol{Z}^{*}$ sebagai berikut:

$$
\boldsymbol{Z}^{* \prime}=\left[\begin{array}{cccccc}
-0,229 & -0,215 & -0,170 & -0,150 & \ldots & -0,014 \\
-0,236 & -0,238 & -0,201 & -0,216 & \ldots & 0.246 \\
-0,196 & -0,203 & -0,191 & -0,190 & \ldots & 0,233 \\
0,247 & 0,228 & 0,201 & 0,197 & \ldots & -0,206 \\
-0,235 & -0,209 & -0,189 & -0,189 & \ldots & 0,143
\end{array}\right](2.7)
$$

Langkah kedua adalah menghitung matriks korelasi gandengan $\left(\boldsymbol{Z}^{* \prime} \boldsymbol{Z}^{*}\right)$, diperoleh:

$$
\boldsymbol{Z}^{* \prime} \boldsymbol{Z}^{*}=\left[\begin{array}{ccccc}
1 & 0,605 & 0,477 & -0,565 & 0,747 \\
0,605 & 1 & 0,973 & -0,912 & 0,930 \\
0,477 & 0,973 & 1 & -0,905 & 0,899 \\
-0,565 & -0,912 & -0,905 & 1 & -0,926 \\
0,747 & 0,930 & 0,899 & -0,926 & 1
\end{array}\right] \text { (2.8) }
$$

Langkah ketiga adalah menghitung akar laten dan vektor laten dari matriks korelasi gandengan berdasarkan persamaan (1.11) dan (1.12), sehingga diperoleh hasil sebagaimana diberikan pada Tabel 4.

Langkah keempat adalah melakukan analisis komponen utama. Kriteria yang digunakan adalah membuang $\left|\lambda_{j}\right| \leq 0,1$ dan $\left|\gamma_{0 j}\right| \leq$ 0,3 (Sharma \& James, 1981, p.157), sehingga didapatkan hasil analisis yang meliputi (1) $\left|\lambda_{4}\right|=4,2191>0,1$ menandakan keadaan bebas linear di antara variabel bebas dan $\left|\gamma_{04}\right|=$ $0,3493>0,3$ sehingga vektor yang bersesuaian tetap dipertahankan; (2) $\left|\lambda_{3}\right|=0,6198>0,1$ menandakan keadaan bebas linear di antara variabel bebas dan $\left|\gamma_{03}\right|=0,8816>0,3$ menandakan keteramalan yang tinggi sehingga vektor yang bersesuaian tetap dipertahankan; (3) $\left|\lambda_{2}\right|=0,1136>0,1$ menandakan keadaan bebas linear di antara variabel bebas sehingga vektor yang bersesuaian tetap dipertahankan walaupun $\left|\gamma_{02}\right|=0,1041<0,3$ menandakan keteramalan yang rendah; (4) $\left|\lambda_{1}\right|=0,0350<0,1$ menandakan kemungkinan adanya keadaan tidak bebas linear di antara variabel bebas dan $\left|\gamma_{01}\right|=$ $0,2087<0,3$ menandakan keteramalan yang rendah sehingga vektor ini dibuang; dan (5) $\left|\lambda_{0}\right|=0,0125<0,1$ menandakan kemungkinan adanya keadaan tidak bebas linear di antara variabel bebas dan $\left|\gamma_{00}\right|=0,2151<0,3$ menandakan keteramalan yang rendah sehingga vektor ini dibuang. 
Pythagoras, 12 (1), 2017 - 30

Desy Pramesti Untari, Mathilda Susanti

\begin{tabular}{ccccccc}
\hline \multirow{2}{*}{ No. } & \multirow{2}{*}{$\boldsymbol{\lambda}_{\boldsymbol{j}}$} & $\boldsymbol{Y}^{*}$ & $\boldsymbol{X}_{\mathbf{1}}^{*}$ & $\boldsymbol{X}_{\mathbf{2}}^{*}$ & $\boldsymbol{X}_{\mathbf{3}}^{*}$ & $\boldsymbol{X}_{\mathbf{4}}^{*}$ \\
\cline { 3 - 7 } & & $\boldsymbol{\gamma}_{\mathbf{0} \boldsymbol{j}}$ & $\boldsymbol{\gamma}_{\mathbf{1}}$ & $\boldsymbol{\gamma}_{\mathbf{j}}$ & $\boldsymbol{\gamma}_{\mathbf{3}}$ & $\boldsymbol{\gamma}_{\mathbf{j}}$ \\
\hline 1 & $\lambda_{4}=4,2191$ & 0,3493 & 0,4737 & 0,4587 & $-0,4623$ & 0,4790 \\
2 & $\lambda_{3}=0,6198$ & 0,8816 & $-0,1828$ & $-0,3745$ & 0,2018 & 0,0912 \\
3 & $\lambda_{2}=0,1136$ & $-0,1041$ & $-0,4402$ & $-0,4106$ & $-0,7763$ & 0,1554 \\
4 & $\lambda_{1}=0,0350$ & 0,2087 & 0,4012 & $-0,098$ & $-0,3654$ & $-0,8077$ \\
5 & $\lambda_{0}=0,0125$ & $-0,2151$ & 0,6224 & $-0,6864$ & 0,0976 & 0,2927 \\
\hline
\end{tabular}

Setelah menentukan akar laten dan vektor laten mana yang tetap dipertahankan, kemudian dibentuk komponen utama berdasarkan koefisien vektor laten. Berdasarkan Persamaan (1.13) dan sesuai Tabel 4, diperoleh tiga komponen utama yang terpilih yaitu sebagai berikut:

$$
\begin{aligned}
C_{1}= & 0,3493 Y^{*}+0,4737 X_{1}^{*}+0,4587 X_{2}^{*}-0,4623 X_{3}^{*} \\
& +0,4790 X_{4}^{*} \\
C_{2}= & 0,8816 Y^{*}-0,1828 X_{1}^{*}-0,3745 X_{2}^{*}+0,2018 X_{3}^{*} \\
& +0,0912 X_{4}^{*} \\
C_{3}= & -0,1041 Y^{*}-0,4402 X_{1}^{*}-0,4106 X_{2}^{*} \\
& -0,7763 X_{3}^{*}+0,1554 X_{4}^{*}
\end{aligned}
$$

dimana

$C_{1}$ : komponen utama yang terbentuk dari vektor laten yang bersesuaian dengan $\lambda_{4}=4,2191$,

$C_{2}$ : komponen utama yang terbentuk dari vektor laten yang bersesuaian dengan $\lambda_{3}=0,6198$, dan

$C_{3}$ : komponen utama yang terbentuk dari vektor laten yang bersesuaian dengan $\lambda_{4}=0,1136$,

Sehingga diperoleh matriks komponen utama $\boldsymbol{C}$ sebagai berikut:

$$
\boldsymbol{C}=\left[\begin{array}{ccc}
-0,508 & -0,057 & -0,020 \\
-0,487 & -0,043 & 0,001 \\
-0,434 & -0,015 & 0,008 \\
-0,423 & 0,001 & 0,006 \\
\vdots & \vdots & \vdots \\
0,382 & -0,173 & -0,021
\end{array}\right]
$$

Kemudian ketiga komponen utama tersebut diregresikan dengan variabel tidak bebas untuk dilakukan uji koefisien determinasi, uji parameter dan uji asumsi. Diperoleh koefisien determinasi $R_{a d j}^{2}=0,998$ yang artinya sebesar 99,8\% keragaman variabel tidak bebas dapat diterangkan oleh variabel-variabel bebas yang digunakan.

Pada uji $F$ diperoleh bahwa $p-$ value $=$ 0 yang berarti bahwa secara simultan variabelvariabel bebas yang digunakan berpengaruh signifikan terhadap variabel tidak bebas. Pada uji $t$ diperoleh bahwa semua nilai $p-$ value $=$ 0 untuk setiap variabel bebas, yang artinya variabel-variabel bebas secara parsial berpengaruh signifikan terhadap variabel tidak bebas.

Kemudian dilakukan uji asumsi regresi yang terdiri dari normalitas, heterokedastisitas,

autokorelasi dan multikolinearitas. Uji normalitas dilakukan melalui Uji Kolmogorov-Smirnov yang diperoleh $p$-value $=0,37$, yang artinya bahwa galat berdistribusi normal. Uji heterokedastisitas dilakukan melalui Uji Glejser yang diperoleh $p$-value $=0,024$ untuk $C_{2}$, sedangkan $p$-value $=0,418$ untuk $C_{1}$ dan $p$-value $=0,216$ untuk $C_{3}$ yang artinya terjadi heterokedastisitas pada $C_{2}$ sedangkan pada $C_{1}$ dan $C_{3}$ tidak terjadi heterokedastisitas. Uji autokorelasi dilakukan melalui Uji Run yang diperoleh $p$-value $=0,466$, yang artinya tidak terjadi autokorelasi. Uji multikolinearitas dilakukan melalui uji korelasi parsial $(r)$ dan uji $V I F$. Nilai $r=0$ atau $V I F=1$ berarti tidak ada korelasi di antara variabel bebas. Diperoleh nilai korelasi parsial dan VIF seperti pada Tabel 5

Tabel 5. Uji Multikolinearitas

\begin{tabular}{ccccr}
\hline $\boldsymbol{r}$ & $\boldsymbol{C}_{\mathbf{1}}$ & $\boldsymbol{C}_{\mathbf{2}}$ & $\boldsymbol{C}_{\mathbf{3}}$ & $\boldsymbol{V I F}$ \\
\hline$C_{1}$ & 1 & 0 & 0 & 1 \\
$C_{2}$ & 0 & 1 & 0 & 1 \\
$C_{3}$ & 0 & 0 & 1 & 1 \\
\hline
\end{tabular}

Dari Tabel 5 dapat dilihat bahwa korelasi antar variabel bebas adalah nol dan $V I F=1$ untuk setiap variabel bebas yang menandakan bahwa masalah multikolinearitas sudah teratasi. Langkah selanjutnya adalah melakukan pendugaan koefisien regresi pada data yang telah dibakukan berdasarkan Persamaan (1.14), (1.15) dan (1.16), diperoleh:

$\hat{\beta}_{1}^{*}=-400,772$
$\hat{\beta}_{2}^{*}=259,983$
$\hat{\beta}_{3}^{*}=-2107,433$
$\hat{\beta}_{4}^{*}=-59,207$
$\hat{\beta}_{0}^{*}=4634,625$

Langkah terakhir analisis latent root regression dalam mengatasi multikolinearitas pada faktor-faktor yang mempengaruhi IHSG di Bursa Efek Indonesia adalah melakukan pendugaan koefisien regresi pada data asal berdasarkan Persamaan (1.17) dan (1.18), diperoleh:

$\hat{\beta}_{1}=-0,00011$
$\hat{\beta}_{2}=0,0235$
$\hat{\beta}_{3}=-1,407$
$\hat{\beta}_{4}=-0,0047$ 
Pythagoras, 12 (1), 2017 - 31

Desy Pramesti Untari, Mathilda Susanti

$\hat{\beta}_{0}=6789,5205$

Sehingga diperoleh persamaan regresi kuadrat terkecil termodifikasi pada data asal adalah

$$
\begin{array}{r}
\hat{Y}=6789,5205-0,00011 X_{1}+0,0235 X_{2} \\
-1,4073 X_{3}-0,0047 X_{4}
\end{array}
$$

\section{Perbandingan Principal Component Regression dan Latent Root Regression}

Berdasarkan analisis principal component regression dan latent root regression dalam mengatasi multikolinearitas pada faktor-faktor yang mempengaruhi IHSG di Bursa Efek Indonesia yang telah dilakukan sebelumnya diperoleh bahwa masing-masing koefisien determinasi $R_{a d j}^{2}$ adalah 0,366 dan 0,998 . Hal tersebut menunjukkan bahwa keragaman variabel tidak bebas yang diterangkan oleh variabelvariabel bebas pada latent root regression lebih kuat dibandingkan principal component regression.

Selain itu, hasil uji asumsi dari analisis principal component regression diperoleh bahwa asumsi normalitas dipenuhi, akan tetapi terjadi pelanggaran asumsi heterokedastisitas dan autokorelasi. Sedangkan hasil uji asumsi dari analisis latent root regression diperoleh bahwa asumsi normalitas, tidak terjadi autokorelasi dan tidak terjadi multikolinearitas dipenuhi, hanya asumsi heterokedastisitas yang dilanggar.

Berdasarkan hasil analisis tersebut dapat disimpulkan bahwa analisis latent root regression lebih baik daripada principal component regression dalam mengatasi multikolinearitas pada faktor-faktor yang mempengaruhi IHSG di Bursa Efek Indonesia karena koefisien determinasi $R_{a d j}^{2}$ lebih besar dan asumsi-asumsi model regresi lebih banyak dipenuhi pada analisis latent root regression dibandingkan pada analisis principal component regression.

\section{SIMPULAN}

Berdasarkan pembahasan dapat disimpulkan bahwa langkah-langkah analisis latent root regression meliputi membakukan data pada variabel tidak bebas dan variabel bebas, menghitung matriks korelasi gandengan, menghitung nilai akar laten dan vektor laten dari matriks korelasi gandengan, melakukan analisis komponen utama pada latent root regression, melakukan pendugaan koefisien regresi pada data baku, dan melakukan pendugaan koefisien regresi pada data asal. Hasil analisis latent root regression yang diterapkan pada faktor-faktor yang mempengaruhi IHSG di Bursa Efek Indonesia menghasilkan persamaan regresi dugaan:

$$
\begin{array}{r}
\hat{Y}=6789,5205-0,00011 X_{1}+0,0235 X_{2} \\
-1,407 X_{3}-0,0047 X_{4},
\end{array}
$$

yang berarti bahwa apabila faktor lain dianggap konstan, maka: untuk setiap kenaikan jumlah uang beredar sebesar satu miliar rupiah akan menurunkan IHSG sebesar 0,00011 satuan; untuk setiap kenaikan kurs rupiah terhadap dolar AS sebesar satu rupiah maka akan menaikkan IHSG sebesar 0,0235 satuan; untuk setiap kenaikan harga emas dunia sebesar satu dolar AS/troy ons maka akan menurunkan IHSG sebesar 1,407 satuan; untuk setiap kenaikan Indeks Dow Jones sebesar satu satuan maka akan menurunkan IHSG sebesar 0,0047 satuan; dan jika semua variabel bebas konstan maka IHSG akan bernilai 6789,5205.

\section{DAFTAR PUSTAKA}

Draper, N.R., \& Smith, H. (1992). Analisis regresi terapan edisi kedua. Penerjemah: Bambang Sumantri. Jakarta: Gramedia Pustaka Utama.

Ernawati, D. (2014). Analisis pengaruh nilai tukar (kurs) Dolar Amerika/Rupiah (US\$/Rp), inflasi, tingkat suku bunga SBI dan jumlah uang beredar $\left(M_{2}\right)$ terhadap indeks harga saham gabungan (IHSG) di Bursa Efek Indonesia (BEI) periode 20062010. Naskah Publikasi. Universitas Muhammadiyah Surakarta.

Gujarati, D.N. (2006). Dasar-dasar ekonometrika jilid 2. Penerjemah: Julius A. Mulyadi. Jakarta: Penerbit Erlangga.

Hasibuan, M.S.P. (2009). Dasar-dasar perbankan. Jakarta: Bumi Aksara.

Kewal, S.S. (2012). Pengaruh inflasi, suku bunga, kurs, dan pertumbuhan PDB terhadap indeks harga saham gabungan. Jurnal Economia, 8(1). 53-64.

Marcus, G.L., Wattimela, H.J., \& Lesnussa, Y.A. (2012). Analisis regresi komponen utama untuk mengatasi masalah multikolinearitas dalam analisis regresi linear berganda (studi kasus: curah hujan di Kota Ambon Tahun 2010. Jurnal Barekeng, Vol. 6, No. 1, Hlm. 31-40. 
Pythagoras, 12 (1), 2017 - 32

Desy Pramesti Untari, Mathilda Susanti

Midi, H., \& Hua, L.U. (2009). The Performance of Latent Root M-based Regression. Journal of Mathematics and Statistics, Vol. 5, No. 1, Hlm. 1-9.

Nopirin. (2000). Pengantar Ilmu Ekonomi Makro \& Mikro. Yogyakarta: BPFE.

Prayitno, H. (2012). Analisis hubungan antara harga emas dunia, kurs rupiah, dan harga crude oil terhadap indeks harga saham gabungan (IHSG) di Bursa Efek Indonesia tahun 2009-2011. Jurnal Akuntansi, Manajemen Bisnis dan Sektor Publik (JAMBSP), Vol. 8, No. 3, Hlm. 418-434.

Riyantini, D.L., Susilawati, M., \& Sari, K. (2014). Penerapan regresi akar laten dalam menangani multikolinearitas pada model regresi linier berganda. E-Jurnal Matematika, Vol. 3, No.1, Hlm. 8-16.

Samsul, M. (2006). Pasar modal dan manajemen portofolio. Jakarta: Penerbit Erlangga.
Sharma, S \& James, W.L. (1981). An alternate procedure for estimating parameters in the presence of multicollinearity. Journal of Marketing Research, Vol. 18, No. 2, Hlm. 154-161.

Sunyoto, D. (2012). Dasar-dasar statistika untuk ekonomi. Yogyakarta: CAPS.

Vigneau, E \& Qannari, E.M. (2002). A new algorithm for latent root regression analysis. Computational Statistics \& Data Analysis 41, 231-242.

Webster, J.T., Gunts, R.F., \& Mason, R. (1974). Latent root regression analysis. Technometrics 16, 513-522.

Witjaksono, A.A. (2010). Analisis pengaruh tingkat suku bunga SBI, harga minyak dunia, harga emas dunia, kurs rupiah, Indeks Nikkei 225, dan Indeks Dow Jones terhadap IHSG (studi kasus pada IHSG di BEI selama periode 2000-2009. Tesis. Universitas Diponegoro 